\title{
Enhancing artemisinin content in and delivery from Artemisia annua: a review of alternative, classical, and transgenic approaches
}

\author{
Kaiser Iqbal Wani ${ }^{1} \cdot$ Sadaf Choudhary $^{1} \cdot$ Andleeb Zehra $^{1} \cdot$ M. Naeem ${ }^{1} \cdot$ Pamela Weathers $^{2} \cdot$ Tariq Aftab $^{1}$ (D)
}

Received: 10 December 2020 / Accepted: 30 June 2021 / Published online: 15 July 2021

(c) The Author(s), under exclusive licence to Springer-Verlag GmbH Germany, part of Springer Nature 2021

\begin{abstract}
Main conclusion This review analyses the most recent scientific research conducted for the purpose of enhancing artemisinin production. It may help to devise better artemisinin enhancement strategies, so that its production becomes cost effective and becomes available to masses.
\end{abstract}

\begin{abstract}
Malaria is a major threat to world population, particularly in South-East Asia and Africa, due to dearth of effective anti-malarial compounds, emergence of quinine resistant malarial strains, and lack of advanced healthcare facilities. Artemisinin, a sesquiterpene lactone obtained from Artemisia аппиa L., is the most potent drug against malaria and used in the formulation of artemisinin combination therapies (ACTs). Artemisinin is also effective against various types of cancers, many other microbes including viruses, parasites and bacteria. However, this specialty metabolite and its derivatives generally occur in low amounts in the source plant leading to its production scarcity. Considering the importance of this drug, researchers have been working worldwide to develop novel strategies to augment its production both in vivo and in vitro. Due to complex chemical structure, its chemical synthesis is quite expensive, so researchers need to devise synthetic protocols that are economically viable and also work on increasing the in-planta production of artemisinin by using various strategies like use of phytohormones, stress signals, bioinoculants, breeding and transgenic approaches. The focus of this review is to discuss these artemisinin enhancement strategies, understand mechanisms modulating its biosynthesis, and evaluate if roots play any role in artemisinin production. Furthermore, we also have a critical analysis of various assays used for artemisinin measurement. This may help to develop better artemisinin enhancement strategies which lead to decreased price of ACTs and increased profit to farmers.
\end{abstract}

Keywords Artemisinin combination therapies (ACTs) - Glandular trichomes · Transgenic technology

\section{Introduction}

Artemisia annua L. belonging to the family Asteraceae is the major source of artemisinin (Qinghaosu), an efficient and promising antimalarial drug synthesized in the glandular trichomes of the aerial parts of the plant (Salehi et al. 2018).

Communicated by Gerhard Leubner.

Tariq Aftab

tarik.alig@gmail.com

1 Department of Botany, Aligarh Muslim University, Aligarh 202 002, India

2 Department of Biology/Biotechnology, Worcester Polytechnic Institute, 100 Institute Rd, Worcester, MA 01609, USA
Artemisinin was discovered in 1972 as a part of Project 523 by screening traditional Chinese medicinal recipes and literature (Miller and Su 2011). Artemisinin-based combination therapies (ACTs) are currently endorsed for the treatment of malaria caused by Plasmodium falciparum (WHO 2006). The treatment and control of malaria is hindered by the occurrence of various and newly emerging multi-drugresistant strains of P. falciparum (Korenromp et al. 2003). The phytomolecule artemisinin, a sesquiterpene lactone characterized by the presence of an endoperoxide bridge (Luo and Shen 1987) is very effective against chloroquine resistant strains of P. falciparum malaria (Enserink 2005; Liu et al. 2006). Artemisinin and its derivatives are not only effective against malaria, but also against various types of cancers and tumors (Efferth 2017), some viruses (Efferth et al. 2008; Efferth 2018) including SARS-CoV-2 (Nair 
et al. 2021), tuberculosis (Martini et al. 2020; Zheng et al. 2017), and many other parasites including Schistosoma sp. (Munyangi et al. 2018), Leishmania sp. (Mesa et al. 2017), Borrelia burgdorferi (Feng et al. 2015), and Trypanosoma sp. (Naß and Efferth 2018). Artemisinins are widely used in the form of herbal preparations in traditional medicine, to treat intermittent fevers. The role of artemisinin in the treatment of malaria was established in the 1970s with the rediscovery of this life saving drug, called qinghao in Chinese (Hsu 2006). Artemisinin is also effective against the strains of Plasmodium sp. responsible for causing cerebral malaria (Abdin and Alam 2015) and other less lethal malaria species including $P$. vivax, and $P$. ovale.

Besides infectious diseases, artemisinin is also efficacious against a number of chronic conditions including fibrosis (Zeng et al. 2015; Dolivo et al. 2020), colitis (Sun et al. 2019) and inflammation (Shi et al. 2015). Antifibrotic mechanisms of artemisinin include inhibition of angiogenesis, ECM deposition, differentiation of myofibroblasts, and downregulation of profibrotic genes (see review by Dolivo et al. 2020). Activity against inflammation occurs mainly via the MAPK and NF- $\mathrm{KB}$ pathways and even per os Artemisia апnиa is effective (Desrosiers et al. 2020).

The amount of artemisinin in A. апnиa L. is generally low (0.01-1.5\% dry weight), which restricts commercialization of this product (Bhakuni et al. 2001; Darki et al. 2019). The scarcity and the high cost of this drug in the developing world makes it a topic of worldwide research. Due to low artemisinin content in A. апnи a plants and being the major source of artemisinin extraction, the global artemisinin cost is quite volatile, for example, ranging in 2011 from US $\$ 896.7 / \mathrm{kg}$ to US $\$ 221.6 / \mathrm{kg}$ in 2015 (https://www. 360marketupdates.com/global-artemisinin-market-14845 688 last accessed Sept. 28, 2020). The increased incidence of drug-resistant malarial strains throughout the world, has resulted in an increase in the demand for artemisinin, which is projected to grow from 176 metric tons (MTs) in 2017 to 218 MTs in 2021, almost a 25\% increase in demand (https:// unitaid.org/assets/Global-malaria-diagnostic-and-artem isinin-treatment-commodities-demand-forecast-2017-\%E2\% 80\%93-2021-Report-May-2018.pdf Last accessed Sept. 28, 2020). A major hindrance in coping with this high demand is the low artemisinin content in A. аппиа L. plants, so profitable commercialization of ACTs is challenging (Arora et al. 2016). The broader potential use of artemisinin will mean greater demand, so there is need to better understand artemisinin production dynamics and to increase its production in plants (in vivo) or in vitro, by understanding mechanisms modulating its biosynthesis.

The biosynthesis of artemisinin mainly occurs inside the 10-celled structures called glandular trichomes, present in the aerial parts of the plant. These glandular trichomes have three pairs of secretory cells and are characterized by high expression of genes associated with secondary metabolism including artemisinin biosynthesis genes (Olsson et al. 2009). The amount of artemisinin varies in different cultivars of A. аппиа. Its content is also responsive to the stage of development (reaching its peak during flowering), light intensity, and the harvest time (Laughlin et al. 1994; Towler and Weathers 2015). Artemisinin production is also affected by environmental factors like chilling stress (Feng et al. 2009), salinity stress (Qureshi et al. 2005), elicitation (Mannan et al. 2010), irradiation (Wang et al. 2001), water stress (Yadav et al. 2014) and soil types and humidity (White 2008). The chemical synthesis of artemisinin (total synthesis and partial synthesis) was also reviewed by Wang et al. (2014) and Paddon and Keasling (2014) to highlight major advances and it has been suggested that researchers need to devise new innovative techniques of chemical synthesis of artemisinin. Enhancement of artemisinin production in the whole plant is recommended because despite recent advances and improved process design (Sixt et al. 2018), chemical synthesis of artemisinin remains costly (Wang et al. 2014). The goal has been to take costs to $\leq$ US $\$ 0.50$ for a full course of treatment (Eastman and Fidock 2009).

New scientific methods need to be devised for artemisinin production, keeping in mind the manufacturing cost, in order to make it accessible to the masses. The effectiveness of artemisinin in the treatment of various kinds of diseases lies in its complex chemical structure, which is also the major hindrance in its chemical synthesis for commercial purposes. Thus, the best way to reduce the gap between its supply and its demand is to increase its yield in the main source plant, $A$. аппиа L., by coordinating various yield enhancement strategies. The focus of this review is to recapitulate the major and latest scientific advances for enhancement of artemisinin in vivo as well as in vitro, so that supply meets demand to save lives of even the neediest of people.

\section{Artemisinin enhancement strategies}

\section{Transgenic approaches}

Transgenics of a number of species of Artemisia have been produced either by introduction of novel genes or by improving expression of endogenous pathways in order to modify the biosynthesis of artemisinin (Ikram and Simonsen 2017). The artemisinin biosynthetic pathway (Fig. 1) is catalyzed by certain key genes that are differentially expressed in various parts of the plant. These include HMGS (HMG-CoA synthase), HMGR (HMG-CoA reductase), DXR (1-deoxy-Dxylulose 5-phosphate reductase), DXS (1-deoxy-D-xylulose 5-phosphate synthase), FPS (farnesyl pyrophosphate synthase), CYP71AVI (cytochrome P450 mono-oxygenase), ADS (amorpha-4, 11-diene synthase), DBR2 (artemisinic 
Fig. 1 Artemisinin biosynthesis via MEP pathway and Mevalonic acid pathway inside plastids and cytosol. ( $A A$ artemisinic acid, $A D S$ amorpha-4, 11-diene synthase, $A L D H 1$ alcohol dehydrogenase $1, A N$ artemisinin, CPR 1 cytochrome $\mathrm{P} 450$ reductase 1, CYP71AV1 cytochrome $P 450$ mono-oxygenase, $D B R 2$ artemisinic aldehyde delta-11(13)-double bond reductase, DHAA dihydroartemisinic acid, DMAPP dimethylallyl pyrophosphate, $D X P$ 1-deoxy-D-xylulose-5-phosphate, $D X R$ 1-deoxy-D-xylulose 5-phosphate reductase, $D X S$ 1-deoxy-D-xylulose 5-phosphate synthase, FPPS farnesyl pyrophosphate synthase, $H M G R$ HMG-CoA reductase, $H M G S$ HMG-CoA synthase, IPP isopentyl pyrophosphate, IPPI isopentenyl pyrophosphate isomerase, MEP 2-C-methylD-erythrytol 4-phosphate)



aldehyde delta-11(13)-double bond reductase) and ALDH1 (alcohol dehydrogenase 1) (Abdin et al. 2003). Various genes involved in artemisinin biosynthesis including FPS, $A D S$ and other associated genes involved in certain competitive pathways like squalene synthase (SQS) have been successfully cloned into A. апnиа (Matsushita et al. 1996; Mercke et al. 2000; Yan et al. 2003). Artemisinin content can be enhanced by over-expressing artemisinin biosynthetic genes, by over-expressing transcription factors of genes involved in artemisinin biosynthesis, or by blocking key genes of pathways competitive to artemisinin biosynthesis.

Artemisinin, derived from the condensation of three 5-carbon isoprenoid molecules originating from both plastid as well as cytosol (Schramek et al. 2010; Towler and Weathers 2007), and HMGR is one of the key regulatory enzymes involved in shunting HMG-CoA into the mevalonate arm of the isoprenoid pathway (Ram et al. 2010). In the plastidic non-mevalonate pathway, DXR catalyzes the first step of 5 carbon isoprenoid synthesis by synthesizing 2-C-methyl-D-erythritol-4-phosphate from 1-deoxy-D-xylulose-5-phosphate. When an HMGR gene from Catharanthus roseus was transferred into $A$. апnиа, resulting transgenic lines had higher $H M G R$ activity compared to the wild type; artemisinin levels increased $22.5-38.9 \%$ compared to wild type (Nafis et al. 2011). HMGR also proved beneficial in synthetic biosynthesis of artemisinin in Saccharomyces cerevisiae. When three copies of $H M G R$ were introduced from A. annua into $S$. cerevisiae, significantly more artemisinic acid was produced than from single gene copies (Paddon et al. 2013). Artemisinin biosynthesis was improved 7.65fold through co-transformation of both $A D S$ and $H M G R$ in A. апnиа (Alam and Abdin 2011) and also by over-expression of both FPS and HMGR in A. аnnua (Wang et al. 2011).

DXR is another key regulator of artemisinin biosynthesis as confirmed by fosmidomycin treatment, an MEP pathway blocker (Towler and Weathers 2007), which inhibits 
the conversion of DXP (1-deoxy-D-xylulose-5-P) into MEP (2-C-methyl-D-erythritol-4-phosphate). Treating A. annua plants with fosmidomycin at $100 \mu \mathrm{M}$ for 14 days decreased artemisinin content by $25 \%$ compared to controls (Towler and Weathers 2007). Those inhibition studies were confirmed by isotopologue profiling by Schramek et al. (2010). The DXR locus co-localizes with the QTL affecting concentration and yield of artemisinin (Graham et al. 2010). Xiang et al. (2012) reported about two-fold more artemisinin in transgenic A. апnua in which the DXR gene was overexpressed using a CaMV35S promoter. Together these results indicate that both $H M G R$ and $D X R$ genes are important in the artemisinin biosynthetic pathway and thus can be used in increasing its production.

The three C5 isoprenoid units produced by the action of HMGR and DXR are condensed by FPS to produce FPP (farnesyl diphosphate), a 15-carbon compound that acts as a branch point from which different types of products are produced. A. апnиa transgenic lines with FPS over-expression showed a three-fold increase in artemisinin (Banyai et al. 2010a; Chen et al. 2000). Transgenic plants produced by introduction of a heterologous FPS gene from Gossypium arboreum resulted in 2-3 times more artemisinin compared to non-transgenic plants (Chen et al. 2000). However, introduction of multiple copies of the FPS gene resulted in decreased artemisinin production, and less than wild type (Banyai et al. 2010a).

FPP is converted into amorpha-4,11-diene by ADS and the pathway is now committed to artemisinin biosynthesis (Bouwmeester et al. 1999). Overexpression of $A D S$ also up-regulates artemisinin biosynthesis. Gas Chromatography $\times$ Gas Chromatography - Mass Spectrometry results of transgenic plant lines with overexpression of $A D S$ showed that the contents of artemisinic acid, dihydroartemisinic acid and artemisinin were increased by about 65,59 and $82 \%$ respectively, as compared to the control transgenic line (Ma et al. 2009a). Feedback inhibition of artemisinin biosynthesis can also occur. Plants sprayed with artemisinic acid had reduced ADS transcripts of ADS A. аппиа (Arsenault et al. 2010).

Amorpha-4,11-diene is converted into artemisinic acid by a three-step oxidation through intermediates artemisinin alcohol and artemisinic aldehyde, catalyzed by the P450 CYP71AV1. CYP71AV1 is co-expressed with cytochrome P450 oxidoreductase (CPR) and CYP71AV1 activity requires CPR as a reducing companion (Ro et al. 2006). The introduction of cloned $C P R$ and $C Y P 71 A V 1$ genes into A. annua with a CaMV35S promotor increased artemisinin by $38 \%$ compared to the WT (Xiang et al. 2012). The cooverexpression of CYP71AV1, CPR and FPS resulted in 3.6fold higher artemisinin in the transgenic line (Chen et al. 2012). Over and co-expression of artemisinin biosynthetic pathway genes, therefore, seem to have a promising impact in increasing artemisinin production.

Plant specialty (aka, secondary) metabolite biosynthetic pathways are also regulated by transcription factors that control the genes coding for enzymes in the pathways (Tang et al. 2014). The first isolated and characterized transcription factor from A. аппиа, AaWRKY1, binds to W boxes (TTG ACC) in both CYP71AVI and ADS promoters thereby activating key genes involved in artemisinin biosynthesis (Ma et al. 2009b). AaWRKYI over-expression results in about fourfold increase in artemisinin content compared to the control (Tang et al. 2014). Yu et al. (2012) reported that $A a E R F 1$ and $A a E R F 2$, jasmonate (JA) responsive transcription factors, positively regulate $A D S$ and $C Y P 71 A V 1$ genes yielding enhanced artemisinic acid and artemisinin content. A trichome specific transcription factor AaORA in A. апnиa also regulates the expression of certain genes. AaORA overexpression in A. апnиa driven by the CaMV35S promoter increases dihydroartemisinic acid and artemisinin levels by up-regulating expression of $A D S, D B R 2, C Y P 71 A V 1$, and AaERF1. AaORA down-regulation by hairpin-mediated RNAi decreased dihydroartemisinic acid as well as artemisinin. Zhou et al. (2020) identified an MYB transcription factor, AaTAR2 which acts as a positive regulator of glandular trichome initiation and development, and its over-expression resulted in increased artemisinin content. Recently, Qin et al. (2021) isolated and characterized another glandular trichome specific transcription factor AaMYB17 in A. аппиа. They reported that $A a M Y B 17$ overexpression lines increased glandular trichome density and artemisinin content, whereas RNAi of AaMYB17 resulted in decreased glandular trichome density. These transcription factors, AaWRKY1, AaERF1, AaERF2, AaORA, and AaMYB17 cloned from A. annua increase artemisinin levels, so they could be used in creating various transgenic cultivars with higher artemisinin content than their wild type parents (Fig. 2).

Most of the studies have identified transcription factors positively regulating artemisinin biosynthesis whereas negative regulators are hardly reported. Wu et al. (2021) identified an R2R3- MYB transcription factor AaMYB15 in $A$. апnиa and reported that its over-expression results in decreased expression of certain key genes $A D S, C Y P, D B R 2$, and $A L D H 1$. It binds the promoter of $A a O R A$ and represses its activity, which indirectly results in decreased artemisinin content. So AaMYB15 may also act as a potential candidate for $A$. апnиа germplasm improvement.

As mentioned before, FPP acts as the common precursor of ADS leading to artemisinin. FPP is also the precursor of various other sesqui and other larger terpenes as shown in Fig. 1. This branching is catalyzed by different sesquiterpene synthases and branches compete with one another for FPP carbon. The initial step of sterol biosynthesis, catalyzed by SQS, acts as a competitor to artemisinin biosynthesis 


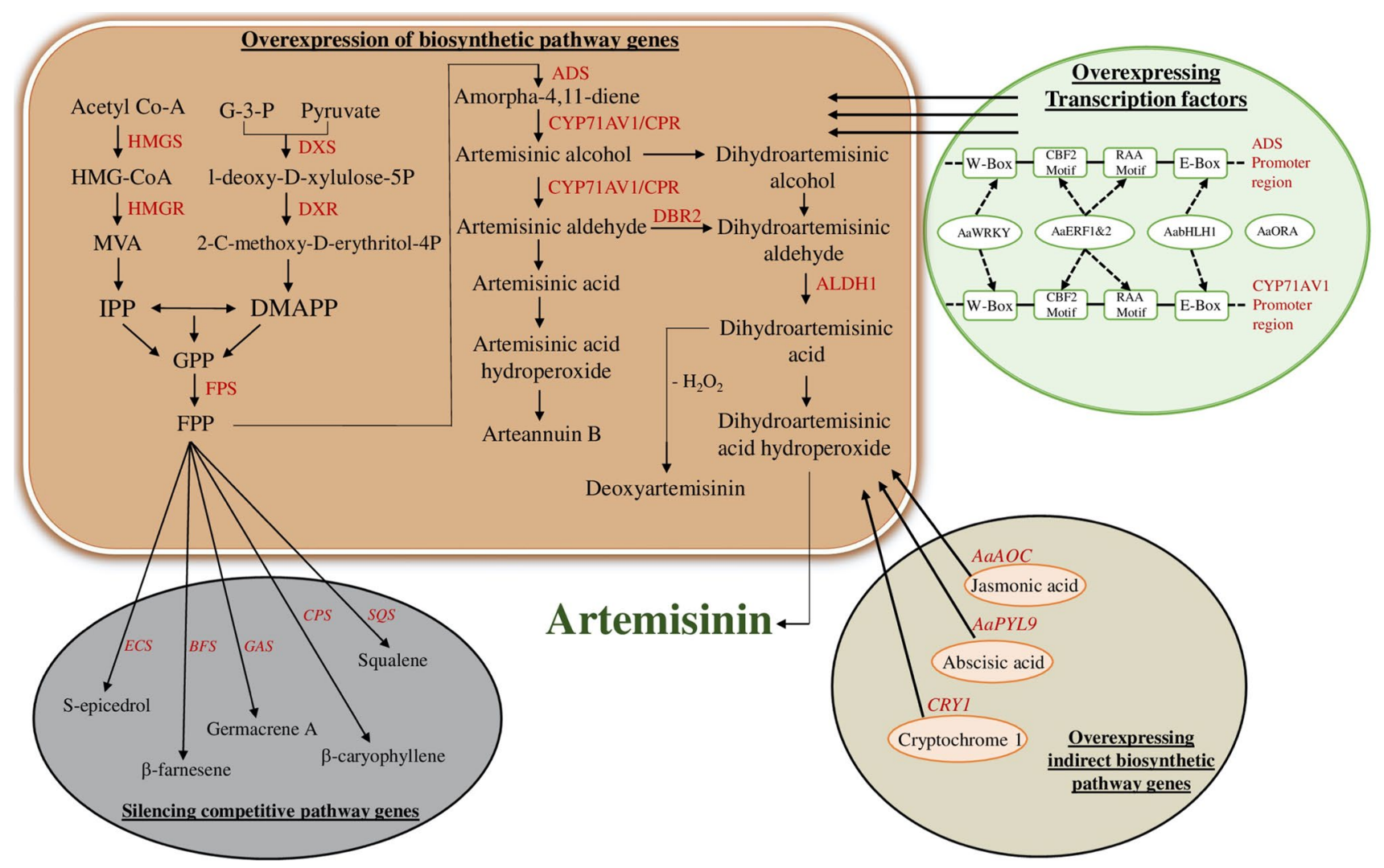

Fig. 2 Mechanistic illustration showing transgenic methods for improved artemisinin biosynthesis in A. аппиа. ( $A D S$ amorpha-4, 11-diene synthase, ALDH1 alcohol dehydrogenase 1, BFS $\beta$-farnesene synthase, $C P R$ cytochrome $\mathrm{P} 450$ reductase, $C P S$ $\beta$-caryophyllene synthase, CYP71AV1 cytochrome P450 mono-oxy-

(Yan et al. 2003). Suppression of SQS by RNAi technology mediated by hpRNA increased artemisinin content in transgenic plants while decreasing sterol content including stigmasterol, campesterol, ergosterol and $\beta$-sitosterol in the transgenic lines (Zhang et al. 2009). The decreased sterol content did not affect plant growth drastically, so that suggested RNAi is a viable alternate platform for increasing artemisinin content.

FPP is also converted into $\beta$-caryophyllene by the enzyme $\beta$-caryophyllene synthase (CPS). Thus, it also acts against artemisinin biosynthesis (Cai et al. 2002). Down-regulation of the $C P S$ gene activity by introduction of an antisense fragment of CPS cDNA into A. annua resulted in a nearly 55\% increase in artemisinin and decreased $\beta$-caryophyllene content (Chen et al. 2011). Therefore, blocking artemisinin competitive pathways also could provide a means for increasing artemisinin content. Coupled with increased expression of artemisinin biosynthetic genes and their transcription factors, these methods appear to be effective without negative effects on plant growth.

One portion of the biosynthetic pathway that has been ignored to date, is post dihydroartemisinic acid metabolism genase, $D B R 2$ artemisinic aldehyde delta-11(13)-double bond reductase, DXR 1-deoxy-D-xylulose 5-phosphate reductase, DXS 1-deoxyD-xylulose 5-phosphate synthase, ECS epicedrol synthase, GAS Germacrene A synthase, HMGR HMG-CoA reductase, HMGS HMGCoA synthase, $S Q S$ squalene synthase)

to undesirable non-therapeutic metabolites, e.g. to deoxyartemisinin (Fig. 1). Although not frequently measured in $A$. аппиа studies, deoxyartemisinin can account for $7.5-12 \%$ of the total measured artemisinin (Towler and Weathers 2015). To our knowledge, no enzyme has been identified catalyzing that reaction. Once identified, however, that enzyme if then blocked could putatively yield a $>10 \%$ increase in artemisinin.

\section{Use of bioinoculants}

Bioinoculants impart value in agriculture due to their role in growth and yield enhancement in various crops (Singh et al. 2016), so they may also serve to improve growth as well as artemisinin content and yield in A. аппиа. Bioinoculants include nitrogen-fixing bacteria and mycorrhizal fungi. These species can increase plant growth and elicit antioxidant responses whereby specialty metabolites are increased even under stressful environmental conditions. The inoculation of Streptomyces sp. MTN14 (STR), Bacillus megaterium MTN2RP (BM) and Trichoderma harzianum Thu (TH) individually as well as in groups, results in enhanced 
artemisinin production, with both dual and triple microbe combinations showing significant results, 20.23-28.57\% and $34.52 \%$ increases, respectively, compared to untreated controls (Gupta et al. 2016). Piriformospora indica (family sebacinaceae), an endophytic fungus that acts as biofertilizer, bioregulator, and bioprotector against various biotic and abiotic stresses and increases the productivity of plants, also increases the artemisinin content in A. аппиа. А. аппиа plants treated with a combination of $P$. indica and Azotobacter chroococcum showed a two-fold increase in artemisinin content compared to controls (Arora et al. 2018). The individual treatment of $A$. апnиa with $P$. indica or A. chroococcum also resulted in artemisinin enhancement to about the same extent (Arora et al. 2016).

Mandal et al. (2015) showed that A. апnиa mutualism with AM fungus Rhizophagus intraradices results in increased artemisinin accumulation due to enhanced expression of certain artemisinin biosynthesis genes, namely $A D S$, CYP71AV1, ALDH1 and DBR2 mediated through enhanced JA levels, most probably due to stimulation of the allene oxide synthase gene. The mycorrhizal infection increased glandular trichome density and transcriptional activation of artemisinin biosynthesis genes. The gene response seemed to mainly act via the MEP pathway because $D X S$ and $D X R$ gene expression increased while $H M G R$ did not. Another AM fungal species of the same genus, $R$. irregularis, also had a positive impact on artemisinin content due to increased glandular trichome density at $40 \%$ greater than the control along with increased guaiacol peroxidase activity for defense against oxidative stress (Domokos et al. 2018).

In another study, Awasthi et al. (2011) used four species of AM fungi Glomus, namely G. mosseae, G. aggregatum, $G$. intraradices and G. fasciculatum, nitrogen fixing bacteria namely Stenotrophomonas spp. and Bacillus subtilis, and showed that combinations of G. mosseae + Bacillus subtilis and G. fasciculatum + Bacillus subtilis resulted in a significant increase in artemisinin content, 26.2 and 24.6\%, respectively, in A. апnиа. Although common in the environment (Berg et al. 1999), Stenotrophomonas, is not recommended as a plant or soil amendment because it is also a recognized MDR human pathogen (Chang et al. 2015). In another study on A. annua, using AM fungi $G$. fasciculatum and $G$. macrocarpum, either alone or supplemented with phosphate fertilizer, glandular trichome density increased significantly, resulting in enhanced artemisinin content, and the fungal impact was greater than phosphate fertilizer application in enhancing artemisinin levels (Kapoor et al. 2007). The increased density of these trichomes in mycorrhizal plants was posited by Torelli et al. (2000) to be the result of increased concentrations of certain hormones like auxins and gibberellins. When $G$. fasciculatum and $G$. macrocarpum, were inoculated on three accessions of $A$. аппиа namely EC 202,429, EC 353,508, and EC 415,012, it resulted in significant increase in the concentration of artemisinin in leaves and certain growth parameters, compared to uninoculated controls. G. macrocarpum resulted in the highest artemisinin concentration in accessions EC 202,429 and EC 353,508 at $0.178 \%$ and $0.221 \%$, respectively, whereas G.s fasciculatum increased artemisinin levels in accession EC 415,012 by $110 \%$ (Chaudhary et al. 2008). The impact of different AM fungi and certain bacteria on A. апnиa demonstrate that these microbes could be used in developing practically useful methods for artemisinin production and may aid in reclamation of marginal lands due to enhanced nutrient acquisition potential.

\section{Use of phytohormones}

Plant growth regulators (PGRs) promote growth and stimulate terpenoid biosynthesis in various kinds of aromatic plants, which may result in beneficial changes in quality as well as quantity of terpenoids (Shukla et al. 1992). Terpenoid biosynthesis requires energy and carbon for which it is dependent on primary metabolism, e.g. oxidative pathways and photosynthesis. Artemisinin production can be increased in A. аппиа through the application of certain PGRs like gibberellins (GAs), abscisic acid (ABA), jasmonic acid (JA) and salicylic acid (SA) (Inthima et al. 2017; Zhou and Memelink 2016; Maes et al. 2011; Banyai et al. 2011; Aftab et al. 2010a, b, 2011b; Pu et al. 2009; Jing et al. 2009). PGR enhancement of artemisinin, recently reviewed by Lv et al. (2017), is updated here.

JA application induces artemisinin biosynthesis by increasing expression of $A a M Y C 2$, a transcription factor that binds to the $D B R 2$ and $C Y P 71 A V 1$ promoters. Using RNAi, overexpression of $A a M Y C 2$ increased expression of $D B R 2$ and $C Y P 71 A V 1$ involved in artemisinin biosynthesis and $A a M Y C 2$ suppression decreased artemisinin biosynthesis (Shen et al. 2016). The treatment of A. апnиa with MeJA increased expression of four genes namely $A D S$, $D B R 2, C Y P 71 A V 1$, and $A L D H 1$ involved in artemisinin biosynthesis; it also enhanced expression of ERF1 and ORA transcription factors (Xiang et al. 2015), which are positive regulators of artemisinin biosynthesis (Yu et al. 2012). $E R F 1$ and $O R A$ expression preceded that of the artemisinin biosynthetic genes, ADS, DBR2, CYP71AV1, and ALDH1. This was not surprising because MeJA activates these transcription factors that in turn activate the biosynthetic genes (Xiang et al. 2015). Ma et al. (2018) reported that JA promotes artemisinin biosynthesis by enabling formation of the TCP14-ORA complex, a positive regulator of artemisinin biosynthesis due to activation of $D B R 2$ and $A L D H 1$ gene promoters. JA also promotes degradation of the AaJAZ8 repressor, a negative regulator of TCP14-ORA complex formation. Li et al. (2019) showed that JA has a positive impact on artemisinin biosynthesis due to its stimulatory effect on 
AaBHLH, which in turn induces artemisinin biosynthetic genes, such as $A D S$ and $C Y P 71 A V 1$. These results suggest that JA biosynthetic genes such as $A a A O C$ and $A a O P R 3$ and JA responsive transcription factors such as AaBHLH, ERF1 and ORA have potential for creating transgenic varieties with increased artemisinin content.

GAs also have a positive regulatory effect on artemisinin content and yield. Metabolome and transcriptome analysis by Ma et al. (2020) revealed that GA and UV-B irradiation coordinately promoted artemisinin accumulation in $A$. annua by up-regulating key biosynthetic genes like $A D S$ and CYP71AV1. Co-overexpression analysis suggested that certain selected NAC and MYB transcription factors regulated the expression of these genes to enhance artemisinin production.

SA also improves artemisinin production. Pu et al. (2009) reported that SA increased artemisinin concentration by upregulating transcription of 3-hydroxy-3-methylglutaryl coenzyme-A reductase (HMGR), which catalyzes the first step of the cytosolic arm of sesquiterpene biosynthesis (Fig. 1). As reported by Lv et al. (2019), SA responsive AaNPR1 interacts with AaTGA6, which then activates artemisinin biosynthetic genes like $A D S$ and $C Y P 71 A V I$ via AaERF1 TF. Together these findings indicate that AaTGA6 is a potential target in genetic engineering increased artemisinin production.

Abscisic acid positively affects artemisinin content and yield in plants as well as in suspension cultures by increasing expression of certain key artemisinin biosynthetic genes including ADS, CYP71AV1, DBR2 and ALDH1 (Zehra et al. 2020; Zebarjadi et al. 2018; Jing et al. 2009). Zhong et al. (2018) reported that ABA modulates artemisinin biosynthesis by regulating $A L D H 1$ gene expression via the $A a A B F 3$ transcription factor. ABA also modulates artemisinin biosynthesis through AabZIP1 and AaPLY9 TFs (Zhang et al. 2013, 2015). The above results suggest that AaABF3, AapLY9 and AaBZIP1 could be useful in genetic engineering A. аппиа for increased artemisinin content.

Most PGRs are involved in regulating artemisinin production in A. аппиа, so it is reasonable in future studies to understand crosstalk among these hormones during artemisinin regulation, which may prove beneficial in devising new innovative strategies for artemisinin enhancement.

\section{Stress signal interventions}

Besides elicitors and plant growth regulators, various environmental stresses like heavy metal pollution, cold, water (drought and flooding), light, pest and disease damage affect accumulation of specialty metabolites in plants including artemisinin in A. апnиа (Xiang et al. 2019; Hao et al. 2019; Soni and Abdin 2017; Yin et al. 2008). Specialty compounds have evolved in plants to provide selective advantage against competitors, for defense, and are essential for various vital plant activities. Various stress conditions hamper plant growth and development and induce oxidative stress leading to production of reactive oxygen species. At moderate levels, some of these stress signals boost artemisinin content in $A$. апnиа. On the other hand, some, e.g. boron stress, negatively impact growth of $A$. апnи tive stress. Boron elevated the activity of various antioxidant enzymes like catalase, peroxidase and superoxide dismutase. The concentration of artemisinin increased by applying a moderate dose $(1 \mathrm{mM})$, however, higher doses of boron decreased artemisinin content (Aftab et al. 2010c). Although there are soils contaminated with heavy metals like $\mathrm{Cd}$ and As, and these increase artemisinin levels in plants (Zhou et al. 2017; Naeem et al. 2019), these approaches are neither safe nor practical and should not be encouraged for use in increasing artemisinin in A. аппиа.

Salinity also has an impact on artemisinin production. Vashisth et al. (2018) reported a $14.68 \%$ increase in artemisinin content in $A$. аnnиa plants under salt stress. They suggested that dihydroartemisinic acid acts as a free radical scavenger, helping to quench increased singlet oxygen, resulting in enhancement of artemisinin as the stable end product (Yang et al. 2010). Treatment of A. апnиа seedlings with $4-6 \mathrm{~g} / \mathrm{l} \mathrm{NaCl}$ increased artemisinin content by $2-3 \%$ (w/w) compared to untreated controls that had $1 \%$ artemisinin content (Qian et al. 2007). The salt stress increase in artemisinin however, may be growth stage specific. Qureshi et al. (2005) showed that $160 \mathrm{mM}$ salt treatment enhanced artemisinin content during early growth phases, posited as the result of non-enzymatic conversion of artemisinic acid into artemisinin due to increasing oxidative stress. However, that is unlikely because artemisinic acid is not an in vivo precursor to artemisinin (Fig. 1). During the later stages, the artemisinin content decreased. Moderate salinity stress (50 and $100 \mathrm{mM} \mathrm{NaCl}$ ) along with SA treatment improved the artemisinin content by 18.3 and $52.4 \%$ respectively, with its content decreasing at $200 \mathrm{mM} \mathrm{NaCl}$ (Aftab et al. 2011a).

Temperature also affects the biosynthesis of artemisinin. Liu et al. (2017) reported that low temperature treatment of Artemisia plants at $4{ }^{\circ} \mathrm{C}$ for 12 to $48 \mathrm{~h}$ increased artemisinin content compared to levels at $0 \mathrm{~h}$. This increase appeared to be the result of an increase in endogenous JA, due to activation of JA biosynthetic genes like LOX1, LOX2, JAR1 and $A O C$ responding to cold stress. The increase in endogenous JA in turn led to enhanced expression of JA-responsive transcription factors, namely octadecanoid-responsive AP2/ERF, ethylene response factor 1, and ethylene response factor 2 . These transcription factors act as transcriptional activators of artemisinin biosynthetic genes including $A D S$, $D B R 2$, CYP71AV1, and ALDH1 (Liu et al. 2017). Expression of these genes occurs in a coordinated manner under low temperature, hinting at the participation of certain specific 
transcription factors in regulating artemisinin biosynthesis under such conditions (Xiang et al. 2019). The bHLH transcription factors, mainly ICEs (inducers of CBF expression) induced by the cold are crucial for cold stress tolerance (Fursova et al. 2009), but their role in terpenoid biosynthesis has not been validated. In A. annua two bHLH transcription factors, AabHLH1 (Ji et al. 2014) and AaMYC2 (Shen et al. 2016) are positive regulators of artemisinin biosynthesis suggesting they may play a role in artemisinin regulation in response to cold stress.

\section{Breeding approaches}

To ensure adequate global supply, continuous efforts are afoot to enhance artemisinin production in native A. аппиа plants that are currently its main commercial source. The most malaria-affected regions of the world are Africa and South-East Asia, with $95 \%$ of the 405,000 malaria deaths in 2018 occurring in Africa (https://www.who.int/newsroom/feature-stories/detail/world-malaria-report-2019 Last accessed Sept. 28, 2020). These developing regions of the world lack advanced infrastructure, but are skilled at agriculture. To increase the supply of artemisinin, the cultivation of $A$. аnпиа could be integrated with various breeding techniques involving conventional as well as new biotechnological approaches (Czechowski et al. 2020). Another reason for increasing the in planta artemisinin content is that dry leaf consumption of $A$. апnua is showing efficacy in human trials (Daddy et al. 2017; Munyangi et al. 2019) and seems resilient against the evolution of artemisinin drug resistance as maybe shown in humans (Daddy et al. 2017) and in Plasmodium yoelii-infected mice (Elfawal et al. 2015). Therefore, in planta production and consumption of artemisinin may prove more effective as a malaria treatment.

Non-transgenic breeding programs have contributed superior cultivars of $A$. апnиa resulting in enhanced artemisinin production (Pulice et al. 2016; Ma et al. 2015; Xie et al. 2016). For example, various hybrid lines with $2 \%$ artemisinin (w/w) have been created by conventional breeding methods by crossing $A$. апnиa with wild plants having high artemisinin levels (Cockram et al. 2012). Chromosome doubling also generated a new tetraploid cultivar, code no. 5GC with high artemisinin content at flower initiation stage (Banyai et al. 2010b). Overall production of artemisinin in other various cultivars developed in laboratories achieved 1-2\% dry weight (Ferreira et al. 2005; Brisibe et al. 2012). Due to the heterozygous nature of $A$. аппиа, however, not all published plant lines are stable over generations; even the transgenic varieties developed in the same laboratory have varying artemisinin content (Delabays et al. 2001). This unstable yield is one of the obstacles in meeting the global artemisinin demand.
To resolve this unstable yield, there are several possible solutions: mutational breeding, transgenic approaches, development of a homozygous cultivar via inbreeding to obtain stable artemisinin producing seed, and clonal propagation of high yielding lines. Modern breeding techniques such as mutation and molecular breeding have opened new avenues for crop improvement. Mutation breeding has the potential to improve one or two characters without effecting the rest of the genotype. A molecular breeding project known as 'The CNAP Artemisia Research Project' at the Centre for Novel Agricultural Products, University of York, UK had the aim of producing high yielding, but not genetically engineered varieties of $A$. аппиа. They screened more than 23,000 parental lines for the desired traits and developed about 768 hybrid lines, of which the 268 most promising hybrids were selected for field trials (Graham et al. 2010; Townsend et al. 2013). After rigorous procedures of selection two hybrid varieties namely Hyb8001r (Zenith) and Hyb1209r (Shennong) with 54.5 and $36.3 \mathrm{~kg} / \mathrm{ha}$ artemisinin, respectively, were commercially released with 8001r outperforming 12 other cultivars (Suberu et al. 2016).

Glandular trichomes are the canonical sites of artemisinin production and their low number is correlated with decreased artemisinin content (Kjaer et al. 2012). Various attempts were made to increase the number of glandular trichomes and in one such study the expression of $\beta$ glucosidase (bgll) gene in A. annua through Agrobacteriumfacilitated transformation resulted in $66 \%$ and $20 \%$ increase in the number of glandular trichomes on flowers and leaves, respectively, which in turn resulted in $2.56 \%$ and $1.4 \%(\mathrm{w} / \mathrm{w})$ increase in artemisinin (Singh et al. 2016). More recently, using an A. апnиa mutant (glandless, GLS) that produces no glandular trichomes and no detectable artemisinin (Duke et al. 1994), non-glandular T-trichomes found in this species also produced detectable artemisinin (Wang et al. 2016; Judd et al. 2019) as further detailed in Sect. 2.6.

Exploiting self-pollination for inbreeding of $A$. аппиа resulted in stable and relatively high artemisinin producing lines (Alejos-Gonzalez et al. 2011). F5 and F6 generation progeny from such crosses have remained stable in morphological characteristics and artemisinin production suggesting they are probably inbred homozygous lines (AlejosGonzalez et al. 2013). By repeated inbreeding using high artemisinin producing lines, one could develop a diversity of stable homozygous cultivars to increase global artemisinin production.

A. аппиа plants not only accumulate artemisinin, but also its precursor dihydroartemisinic acid and artemisinic acid (Ferreira and Luthria 2010). Based on seasonal and differential sesquiterpene accumulation, Ferreira et al. (2018) suggested that selecting for high dihydroartemisinic acid and artemisinin but low artemisinic acid can be a useful approach for selection and breeding to produce plants with 
more efficient conversion of dihydroartemisinic acid into artemisinin.

To obtain stable plants from unstable, but high artemisinin yielding A. апnиа lines, clonal propagation via rooted cuttings can be used to maintain high productivity. Although most in vitro methods of propagation would be prohibitively expensive and also risk loss of productivity if cultures dedifferentiate, A. аппиа readily roots from shoot cuttings grown in soil for 2-3 weeks. The Weathers lab recently reported artemisinin levels and total flavonoid content of the SAM cultivar of A. annua that was propagated at least annually over 7 yrs only by rooted cuttings and grown in different soil locations, in pots in growth chambers and on lighted windowsills (Gruessner et al. 2019). Analysis of dried leaf samples harvested pre-anthesis over that time had artemisinin and total flavonoid contents of $1.3 \pm 0.2 \%$ and $0.5 \pm 0.09 \%(\mathrm{w} / \mathrm{w})$, respectively. Combining conventional hybridization and selection with clonal propagation of high yielding genotypes may also serve as a means of enhancing artemisinin production. Clonally propagated high artemisinin yielding A. annua plants show uniformity and yield high artemisinin content homogenously as compared to seed derived plants (Wetzstein et al. 2018).

\section{Genome editing using CRISPR/Cas9}

CRISPR/cas9 (clustered regularly interspaced short palindromic repeats/CRISPR-associated protein Cas9) is the most advanced system for genome editing and can be used to induce a targeted-mutation (Koerniati and Simanjuntak, 2020). To increase artemisinin content of $A$. апnиa, the expression of the $S Q S$ gene must be inhibited. To inactivate this gene, CRISPR/Cas9 can be used to induce a targetedmutation. CRISPR/Cas9 is revolutionizing genome editing technology with minimal off-targets in the present era. Genome editing using CRISPR/Cas9 utilizes a 20-bp guide RNA (gRNA) sequence that uses base pairing to direct Cas9 nuclease to target site and generates double-strand breaks (DSB). Following DSB is the DNA repair process which often introduces mutations (Yang et al. 2017). Besides gene deletions, CRISPR/Cas9 is useful for inserting specific DNA fragment into target sites and specifically altering the transcriptional activity of genes by fusing transcriptional activation or repression domains to an inactivated Cas9 (Lowder et al. 2015). Therefore, from recent research, it is evident that this technology can be used for creating A. апnи lines for higher artemisinin production.

\section{Do roots hold a key?}

Early experiments that measured artemisinin in the in vitro cultured shoots of $A$. аппиа \pm roots showed there was more artemisinin in shoots that had roots (Ferreira and Janick
1996). When roots were removed, shoot artemisinin and arteannuin B declined by 53\% and $60 \%$, respectively. These results were corroborated by Nguyen et al. (2013) who showed that rooted shoots increased their artemisinin level mainly by enlarging the glandular trichomes, but not by increasing their number. In a follow-up study, Wang et al. (2016) used the glandless A. апnиа mutant (GLS) in grafting studies. GLS produces no glandular trichomes and no detectable artemisinin (Duke et al. 1994). They grafted GLS shoots onto high producing ( $1.5 \% \mathrm{w} / \mathrm{w}$ artemisinin) A. апnи $\mathrm{cv}$. SAM roots and GLS shoots subsequently produced detectable amounts $(0.17 \mathrm{mg} / \mathrm{g} \mathrm{FW})$ of artemisinin. Interestingly, the GLS shoots did not produce any detectable glandular trichomes. GLS does have, however, a plethora of the T-trichomes and those were posited as the site of the artemisinin produced in the GLS shoots. Those results were later corroborated by Judd et al. (2019) who showed that the non-glandular, T-trichomes in A. аппиа GLS expressed the genes responsible for artemisinin biosynthesis. Also detected were small amounts of artemisinin localized to the T-trichomes as verified by mass spectrometry image analysis using an, IR-MALDESI system. Together these studies provide compelling evidence of a root specific signal that enhances artemisinin biosynthesis, but is not necessarily localized to the glandular trichomes. Further studies are needed to identify this signal with the aim of potentially harnessing it to increase artemisinin biosynthesis in not only glandular, but also non-glandular trichomes.

\section{Are high technology solutions needed?}

Traditionally A. аппиа was used as tea infusion and a recent positive clinical test in humans (Munyangi et al. 2019) suggested the plant is quite effective at eliminating various stages of the malaria parasite including gametocytes, which has been now verified in vitro (Snider and Weathers 2021). Given that many of the diseases, e.g. malaria, schistosomiasis, leishmania etc., that have responded to treatments using A. апnиa tea infusions (Munyangi et al. 2018, 2019) or other forms of directly using the plant, e.g. encapsulated powdered leaves (Onimus et al. 2013; Mesa et al. 2017) or compressed leaf tablets (Daddy et al. 2017), obtaining ever increasing levels of artemisinin may not be as critically needed as previously considered. Indeed, Desrosiers et al. (2020) showed that in rats artemisinin distributes in greater quantities to serum, tissues and organs when delivered from the plant than as the pure drug, resulting in greater downstream biological responses, e.g. reduction of inflammation markers TNF- $\alpha$ and IL-6. Nevertheless, a source of pure drug will be in demand by the pharmaceutical industry, so A. апnиa plantations and/or artemisinin synthesis using yeast, $E$. coli 
or Physcomitrella patens platforms (Ikram et al. 2017) will still be needed.

\section{Caveats about artemisinin assays of plant extracts}

While evaluating the different artemisinin enhancement strategies, it is important to be aware of the methods that investigators use to measure artemisinin content in extracts of A. аппиа. There is considerable inconsistency in the amount of quantified artemisinin present in the extracts depending on the use of different analytical methods (Lapkin et al. 2009) and thus researchers need to use more definitive assays that validate artemisinin content. A TLC method with $p$-anisaldehyde staining that is specific for terpenes staining dark blue can quantify artemisinin, which stains a distinctive fuchsia color (Widmer et al. 2007). TLC can provide both a phytochemical fingerprint and when compared to a known standard of artemisinin, can also validate artemisinin content in extracts (Widmer et al. 2007; Khan et al. 2015). After scanning a stained TLC plate, also containing a known amount of standard, artemisinin can be quantified using Image $\mathbf{J}$ that is freely available at NIH (https:// imagej.nih.gov/ij/download.html). Many investigators use the HPLC Q260 method of analysis, but it can result in false positives regarding artemisinin mainly because it cannot distinguish between artemisinin and deoxyartemisinin (Lapkin et al. 2009; Christen and Veuthey 2001; Smith et al. 2010). Deoxyartemisinin can account for $>10 \%$ of total artemisinin (Towler and Weathers 2015). Therefore, to provide definitive measurement, and to identify minute impurities $( \pm 2 \%)$ more sensitive methods, which use MS detection, e.g. LCMS (Lapkin et al. 2009) are preferred with lower technology quantitative TLC methods and artemisinin-specific staining also an acceptable option.

\section{Conclusions}

Although there are different strategies for enhancing artemisinin yield, it is still a challenge for any single approach to meet the global artemisinin demand. Therefore, efforts to increase the artemisinin production both in vivo and in vitro continue. Certain strategies like manipulating phytohormone levels, elicitation and breeding of high yielding varieties have been only modestly effective. Therefore, we need to look beyond these approaches and use alternatives like heterologous systems and engineering the metabolic pathway to increase its production in a cost-effective manner to fulfill the demand of this desired therapeutic drug against malaria. The chemical synthesis of artemisinin (both semi synthesis and total synthesis), over-expression of key biosynthetic genes, blocking of competitive pathways through anti-sense RNA technology, and silencing of negatively regulating transcription factors like $A a M Y B 15$ could be helpful in increasing its production. Similarly, direct consumption of the plant material could prove most cost effective of all approaches. The sole aim of this review is to help identify better strategies for artemisinin enhancement, so that it becomes more available to the common masses. This could then also encourage research into production of other pharmaceutical agents.

Author contribution statement TA conceived and designed the first draft, contributed to the revisions and was the advisor of this project. KIW, SC and AZ wrote the first draft of the manuscript with support from MN. PW written portions of Introduction, Breeding Approaches, Use of Bioinoculants, Are high technology solutions needed?, Caveats about artemisinin assays of plant extracts" and critically edited the manuscript. All authors read and approved final version of manuscript.

Acknowledgements This work was funded in part by an award to PJW from The National Center for Complementary and Integrative Health, award number NIH-2R15AT008277-02. The content is solely the responsibility of the authors and does not necessarily represent the official views of the National Center for Complementary and Integrative Health or the National Institutes of Health.

\section{References}

Abdin MZ, Alam P (2015) Genetic engineering of artemisinin biosynthesis: prospects to improve its production. Acta Physiol Plant 37:33. https://doi.org/10.1007/s11738-015-1771-5

Abdin MZ, Israr M, Rehman RU, Jain SK (2003) Artemisinin, a novel antimalarial drug: biochemical and molecular approaches for enhanced production. Planta Med 69:289-299. https://doi.org/ 10.1055/s-2003-38871

Aftab T, Khan MMA, Idrees M, Naeem M, Hashmi N (2010a) Effects of gibberellic acid on growth, photosynthetic efficiency and artemisinin content of Artemisia annua L. Med Aromat Plant Sci Biotechnol 5:25-29

Aftab T, Khan MMA, Idrees M, Naeem M, Singh M, Ram M (2010b) Stimulation of crop productivity, photosynthesis and artemisinin production in Artemisia аппиа L. by triacontanol and gibberellic acid application. J Plant Interact 5:273-281. https://doi.org/10. 1080/17429141003647137

Aftab T, Khan MMA, Idrees M, Naeem M, Ram M (2010c) Boron induced oxidative stress, antioxidant defence response and changes in artemisinin content in Artemisia аппиа L. J Agron Crop Sci 196:423-430. https://doi.org/10.1111/j.1439-037X. 2010.00427.x

Aftab T, Khan MMA, da Silva JAT, Idrees M, Naeem M (2011a) Role of salicylic acid in promoting salt stress tolerance and enhanced artemisinin production in Artemisia aпnиа L. J Plant Growth Regul 30:425-435. https://doi.org/10.1007/s00344-011-9205-0

Aftab T, Khan MMA, Idrees M, Naeem M, Hashmi N (2011b) Methyl jasmonate counteracts boron toxicity by preventing oxidative stress and regulating antioxidant enzyme activities and 
artemisinin biosynthesis in Artemisia аппиа L. Protoplasma 248:601-612. https://doi.org/10.1007/s00709-010-0218-5

Alam P, Abdin M (2011) Over-expression of HMG-CoA reductase and amorpha-4, 11-diene synthase genes in Artemisia annua L. and its influence on artemisinin content. Plant Cell Rep 30:19191928. https://doi.org/10.1007/s00299-011-1099-6

Alejos-Gonzalez F, Qu GS, Zhou LL, Saravitz CH, Shurtleff JL, Xie DY (2011) Characterization of development and artemisinin biosynthesis in self-pollinated Artemisia annиa plants. Planta 234:685-697. https://doi.org/10.1007/s00425-011-1430-z

Alejos-Gonzalez F, Perkins K, Winston MI, Xie DY (2013) Efficient somatic embryogenesis and organogenesis of self-pollination Artemisia annua progeny and artemisinin formation in regenerated plants. Am J Plant Sci 4:2206. https://doi.org/10.4236/ajps. 2013.411274

Arora M, Saxena P, Choudhary DK, Abdin MZ, Varma A (2016) Dual symbiosis between Piriformospora indica and Azotobacter chroococcum enhances the artemisinin content in Artemisia аппиа L. World J Microbiol Biotechnol 32:19. https://doi.org/ 10.1007/s11274-015-1972-5

Arora M, Saxena P, Abdin MZ, Varma A (2018) Interaction between Piriformospora indica and Azotobacter chroococcum governs better plant physiological and biochemical parameters in Artemisia annua $\mathrm{L}$. plants grown under in vitro conditions. Symbiosis 75:103-112. https://doi.org/10.1007/s13199-017-0519-y

Arsenault PR, Vail DR, Wobbe KK, Weathers PJ (2010) Effect of sugars on artemisinin production in Artemisia апnиа L. transcription and metabolite measurements. Molecules 15:23022318. https://doi.org/10.3390/molecules 15042302

Awasthi A, Bharti N, Nair P, Singh R, Shukla AK, Gupta MM, Kalra A (2011) Synergistic effect of Glomus mosseae and nitrogen fixing Bacillus subtilis strain Daz26 on artemisinin content in Artemisia annua L. Appl Soil Ecol 49:125-130. https://doi. org/10.1016/j.apsoil.2011.06.005

Banyai W, Kirdmanee C, Mii M, Supaibulwatana K (2010a) Overexpression of farnesyl pyrophosphate synthase $(F P S)$ gene affected artemisinin content and growth of Artemisia annua L. Plant Cell Tissue Organ Cult 103:255-265. https://doi.org/ 10.1007/s11240-010-9775-8

Banyai W, Sangthong R, Karaket N, Inthima P, Mii M, Supaibulwatana K (2010b) Overproduction of artemisinin in tetraploid Artemisia annua L. Plant Biotechnol 27:427-433. https://doi. org/10.5511/plantbiotechnology.10.0726a

Banyai W, Mii M, Supaibulwatana K (2011) Enhancement of artemisinin content and biomass in Artemisia annua by exogenous GA3 treatment. Plant Growth Regul 63:45-54. https://doi.org/ 10.1007/s10725-010-9510-9

Berg G, Roskot N, Smalla K (1999) Genotypic and phenotypic relationships between clinical and environmental isolates of Stenotrophomonas maltophilia. J Clin Microbiol 37:3594-3600. https://doi.org/10.1128/JCM.37.11.3594-3600.1999

Bhakuni RS, Jain DC, Sharma RP, Kumar S (2001) Secondary metabolites of Artemisia annua and their biological activity. Curr Sci 35-48

Bouwmeester HJ, Wallaart TE, Janssen MH, van Loo B, Jansen BJ, Posthumus MA, Franssen MC (1999) Amorpha-4, 11-diene synthase catalyses the first probable step in artemisinin biosynthesis. Phytochemistry 52:843-854. https://doi.org/10.1016/ S0031-9422(99)00206-X

Brisibe EA, Udensi O, Chukwurah PN, de Magalhäes PM, Figueira GM, Ferreira JF (2012) Adaptation and agronomic performance of Artemisia апnиа L. under lowland humid tropical conditions. Ind Crops Prod 39:190-197. https://doi.org/10. 1016/j.indcrop.2012.02.018

Cai Y, Jia JW, Crock J, Lin ZX, Chen XY, Croteau R (2002) A cDNA clone for $\beta$-caryophyllene synthase from Artemisia аппиа. Phytochemistry 61:523-529. https://doi.org/10.1016/ S0031-9422(02)00265-0

Chang YT, Lin CY, Chen YH, Hsueh PR (2015) Update on infections caused by Stenotrophomonas maltophilia with particular attention to resistance mechanisms and therapeutic options. Front Microbiol 6:893. https://doi.org/10.3389/fmicb.2015.00893

Chaudhary V, Kapoor R, Bhatnagar AK (2008) Effectiveness of two arbuscular mycorrhizal fungi on concentrations of essential oil and artemisinin in three accessions of Artemisia annиa $\mathrm{L}$. Appl Soil Ecol 40:174-181. https://doi.org/10.1016/j.apsoil. 2008.04.003

Chen DH, Ye HC, Li GF (2000) Expression of a chimeric farnesyl diphosphate synthase gene in Artemisia annua L. transgenic plants via Agrobacterium tumefaciens-mediated transformation. Plant Sci 155:179-185. https://doi.org/10.1016/S01689452(00)00217-X

Chen JL, Fang HM, Ji YP, Pu GB, Guo YW, Huang LL, Du ZG, Liu BY, Ye HC, Li GF, Wang H (2011) Artemisinin biosynthesis enhancement in transgenic Artemisia annua plants by downregulation of the $\beta$-caryophyllene synthase gene. Planta Med 77:1759-1765. https://doi.org/10.1055/s-0030-1271038

Chen Y, Shen Q, Wang Y, Wang T, Wu S, Zhang L, Gao E (2012) The stacked over-expression of FPS, CYP71AV1 and CPR genes leads to the increase of artemisinin level in Artemisia annиa L. Plant Biotechnol Rep 7:287-295. https://doi.org/10.1007/ s11816-012-0262-z

Christen P, Veuthey JL (2001) New trends in extraction, identification and quantification of artemisinin and its derivatives. Curr Med Chem 8:1827-1839. https://doi.org/10.2174/0929867013371563

Cockram J, Hill C, Burns C, Arroo RR, Woolley JG, Flockart I, Greenland AJ (2012) Screening a diverse collection of Artemisia апnиа germplasm accessions for the antimalarial compound, artemisinin. Plant Genet Resour 10:152-154. https://doi.org/10. 1017/S1479262112000159

Czechowski T, Weathers PJ, Brodelius PE, Brown GD, Graham IA (2020) Editorial: artemisinin - from traditional chinese medicine to artemisinin combination therapies; four decades of research on the biochemistry, physiology, and breeding of Artemisia annиа. Front Plant Sci 11:594565. https://doi.org/10.3389/fpls.2020. 594565

Daddy NB, Kalisya LM, Bagire PG, Watt RL, Towler MJ, Weathers PJ (2017) Artemisia annua dried leaf tablets treated malaria resistant to ACT and iv artesunate. Phytomedicine 32:37-40. https:// doi.org/10.1016/j.phymed.2017.04.006

Darki BS, Shabani L, Pourvaez R, Mostafa S (2019) Effects of CuSO4 and $\mathrm{AgNO} 3$ on artemisinin and phenolic compound in shoot cultures of Artemisia апnиa L. J Plant Proc Func 8:2

Delabays N, Simonnet X, Gaudin M (2001) The genetics of artemisinin content in Artemisia annua L. and the breeding of high yielding cultivars. Curr Med Chem 8:1795-1801. https://doi.org/10.2174/ 0929867013371635

Desrosiers MR, Mittelman A, Weathers PJ (2020) Dried leaf Artemisia Апnиа improves bioavailability of artemisinin via cytochrome P450 inhibition and enhances artemisinin efficacy downstream. Biomolecules 10:254. https://doi.org/10.3390/biom10020254

Dolivo D, Weathers P, Dominko T (2021) Artemisinin and artemisinin derivatives as antifibrotic therapeutics. Acta Pharm Sin B. 11:322-339. https://doi.org/10.1016/j.apsb.2020.09.001

Domokos E, Jakab-Farkas L, Darkó B, Bíró-Janka B, Mara G, Albert C, Balog A (2018) Increase in Artemisia annua plant biomass artemisinin content and guaiacol peroxidase activity using the arbuscular mycorrhizal fungus Rhizophagus irregularis. Front Plant Sci 9:478. https://doi.org/10.3389/fpls.2018.00478

Duke MV, Paul RN, Elsohly HN, Sturtz G, Duke SO (1994) Localization of artemisinin and artemisitene in foliar tissues of glanded 
and glandless biotypes of Artemisia апnиa L. Int J Plant Sci 155:365-372. https://doi.org/10.1086/297173

Eastman RT, Fidock DA (2009) Artemisinin-based combination therapies: a vital tool in efforts to eliminate malaria. Nat Rev Microbiol 7:864-874. https://doi.org/10.1038/nrmicro2239

Efferth T (2017) From ancient herb to modern drug: Artemisia annua and artemisinin for cancer therapy. Seminars in cancer biology, vol 46. Academic Press, Cambridge, pp 65-83. https://doi.org/ 10.1016/j.semcancer.2017.02.009

Efferth T (2018) Beyond malaria: the inhibition of viruses by artemisinin-type compounds. Biotechnol Adv 36:1730-1737. https:// doi.org/10.1016/j.biotechadv.2018.01.001

Efferth T, Romero MR, Wolf DG, Stamminger T, Marin JJ, Marschall M (2008) The antiviral activities of artemisinin and artesunate. Clin Infect Dis 47:804-811. https://doi.org/10.1086/591195

Elfawal MA, Towler MJ, Reich NG, Weathers PJ, Rich SM (2015) Dried whole-plant Artemisia апnиа slows evolution of malaria drug resistance and overcomes resistance to artemisinin. PNAS 112:821-826. https://doi.org/10.1073/pnas.1413127112

Enserink M (2005) Source of new hope against malaria is in short supply: new drugs based on an old Chinese cure could save countless lives in Africa, if health agencies and companies can find ways to make enough. Science 307:33

Feng LL, Yang RY, Yang XQ, Zeng XM, Lu WJ, Zeng QP (2009) Synergistic re-channeling of mevalonate pathway for enhanced artemisinin production in transgenic Artemisia annua. Plant Sci 177:57-67. https://doi.org/10.1016/j.plantsci.2009.03.014

Feng J, Weitner M, Shi W, Zhang S, Sullivan D, Zhang Y (2015) Identification of additional anti-persister activity against Borrelia burgdorferi from an FDA drug library. Antibiotics 4:397-410. https://doi.org/10.3390/antibiotics4030397

Ferreira JFS, Janick J (1996) Roots as an enhancing factor for the production of artemisinin in shoot cultures of Artemisia аппиа. Plant Cell Tiss Org 44:211-217. https://doi.org/10.1007/BF00048526

Ferreira JFS, Luthria DL (2010) Drying affects artemisinin, dihydroartemisinic acid, artemisinic acid, and the antioxidant capacity of Artemisia annua L. leaves. J Agric Food Chem 58:1691-1698. https://doi.org/10.1021/jf903222j

Ferreira JFS, Laughlin J, Delabays N, De Magalhães PM (2005) Cultivation and genetics of Artemisia аппиа L. for increased production of the antimalarial artemisinin. Plant Genet Resour 3:206-229. https://doi.org/10.1079/PGR200585

Ferreira JF, Benedito VA, Sandhu D, Marchese JA, Liu S (2018) Seasonal and differential sesquiterpene accumulation in Artemisia апnиа suggest selection based on both artemisinin and dihydroartemisinic acid may increase artemisinin in planta. Front Plant Sci 9:1096

Fursova OV, Pogorelko GV, Tarasov VA (2009) Identification of ICE2, a gene involved in cold acclimation which determines freezing tolerance in Arabidopsis thaliana. Gene 429:98-103. https://doi. org/10.1016/j.gene.2008.10.016

Graham IA, Besser K, Blumer S, Branigan CA, Czechowski T, Elias L, Larson TR (2010) The genetic map of Artemisia annua L. identifies loci affecting yield of the antimalarial drug artemisinin. Science 327:328-331. https://doi.org/10.1126/science.1182612

Gruessner BM, Cornet-Vernet L, Desrosiers MR, Lutgen P, Towler MJ, Weathers PJ (2019) It is not just artemisinin: Artemisia sp. for treating diseases including malaria and schistosomiasis. Phytochem Rev 18:1509-1527. https://doi.org/10.1007/ s11101-019-09645-9

Gupta R, Singh A, Gupta MM, Pandey R (2016) Cumulative role of bioinoculants on growth, antioxidant potential and artemisinin content in Artemisia annиa L. under organic field conditions. World J Microb Biot 32:167. https://doi.org/10.1007/ s11274-016-2130-4
Hao X, Zhong Y, Nützmann HW, Fu X, Yan T, Shen Q, Tang K (2019) Light-induced artemisinin biosynthesis is regulated by the bZIP transcription factor AaHY5 in Artemisia annua. Plant Cell Physiol 60:1747-1760. https://doi.org/10.1093/pcp/pcz084

Hsu E (2006) Reflections on the 'discovery'of the antimalarial qinghao. Br J Clin Pharmacol 61:666-670. https://doi.org/10.1111/j.13652125.2006.02673.x

Ikram NK, Simonsen HT (2017) A review of biotechnological artemisinin production in plants. Front Plant Sci 8:1966

Ikram NKB, Kashkooli AB, Peramuna AV, van der Krol AR, Bouwmeester H, Simonsen HT (2017) Stable production of the antimalarial drug artemisinin in the Moss Physcomitrella patens. Front Bioeng Biotechnol 5:47. https://doi.org/10.3389/fbioe. 2017.00047

Inthima P, Nakano M, Otani M, Niki T, Nishijima T, Koshioka M, Supaibulwatana K (2017) Overexpression of the gibberellin 20-oxidase gene from Torenia fournieri resulted in modified trichome formation and terpenoid metabolities of Artemisia апnиa L. Plant Cell Tissue Organ Cult 129:223-236. https:// doi.org/10.1007/s11240-017-1171-1

Ji Y, Xiao J, Shen Y, Ma D, Li Z, Pu G, Wang H (2014) Cloning and characterization of AabHLH1, a bHLH transcription factor that positively regulates artemisinin biosynthesis in Artemisia annua. Plant Cell Physiol 55:1592-1604. https://doi.org/10. 1093/pcp/pcu090

Jing F, Zhang L, Li M, Tang Y, Wang Y, Wang Y, Tang K (2009) Abscisic acid (ABA) treatment increases artemisinin content in Artemisia annua by enhancing the expression of genes in artemisinin biosynthetic pathway. Biologia 64:319-323. https:// doi.org/10.2478/s11756-009-0040-8

Judd R, Bagley MC, Li M, Zhu Y, Lei C, Yuzuak S et al (2019) Artemisinin biosynthesis in non-glandular trichome cells of Artemisia annua. Mol Plant 12:704-714. https://doi.org/10. 1016/j.molp.2019.02.011

Kapoor R, Chaudhary V, Bhatnagar AK (2007) Effects of arbuscular mycorrhiza and phosphorus application on artemisinin concentration in Artemisia annua L. Mycorrhiza 17:581-587. https:// doi.org/10.1007/s00572-007-0135-4

Khan S, Ali A, Ahmad S, Abdin MZ (2015) Affordable and rapid HPTLC method for the simultaneous analysis of artemisinin and its metabolite artemisinic acid in Artemisia annua L. Biomed Chromatogr 29:1594-1603. https://doi.org/10.1002/ bmc. 3465

Kjær A, Grevsen K, Jensen M (2012) Effect of external stress on density and size of glandular trichomes in full-grown Artemisia апnиa, the source of anti-malarial artemisinin. AoB Plants. https://doi.org/10.1093/aobpla/pls018

Koerniati S, Simanjuntak G (2020) CRISPR/Cas9 system for disruption of biochemical pathway for sterol synthesis in Artemisia апnи L. IOP Conf Series Earth Environ Sci 482:12028. https:// doi.org/10.1088/1755-1315/482/1/012028

Korenromp EL, Williams BG, Gouws E, Dye C, Snow RW (2003) Measurement of trends in childhood malaria mortality in Africa: an assessment of progress toward targets based on verbal autopsy. Lancet Infect Dis 3:349-358. https://doi.org/10.1016/s14733099(03)00657-1

Lapkin AA, Walker A, Sullivan N, Khambay B, Mlambo B, Chemat S (2009) Development of HPLC analytical protocols for quantification of artemisinin in biomass and extracts. J Pharmaceut Biomed 49:908-915. https://doi.org/10.1016/j.jpba.2009.01.025

Laughlin JC (1994) The influence of distribution of antimalarial constituents in Artemisia апnиa L. on time and method of harvest. Internat Symp Med Aromat Plants 390:67-74

Li L, Hao X, Liu H, Wang W, Fu X, Ma Y, Tang K (2019) Jasmonic acid-responsive AabHLH1 positively regulates artemisinin 
biosynthesis in Artemisia annua. Biotechnol Appl Biochem 66:369-375. https://doi.org/10.1002/bab.1733

Liu C, Zhao Y, Wang Y (2006) Artemisinin: current state and perspectives for biotechnological production of an antimalarial drug. Appl Microbiol Biot 72:11-20. https://doi.org/10.1007/ s00253-006-0452-0

Liu W, Wang H, Chen Y, Zhu S, Chen M, Lan X, Liao Z (2017) Cold stress improves the production of artemisinin depending on the increase in endogenous jasmonate. Biotechnol Appl Bioc 64:305-314. https://doi.org/10.1002/bab.1493

Lowder LG, Zhang D, Baltes NJ, Paul JW, Tang X, Zheng X, Voytas DF, Hsieh T, Zhang Y, Qi Y (2015) A CRISPR/Cas9 toolbox for multiplexed plant genome editing and transcriptional regulation. Plant Physiol 169:971-985

Luo XD, Shen CC (1987) The chemistry, pharmacology, and clinical applications of qinghaosu (artemisinin) and its derivatives. Med Res Rev 7:29-52. https://doi.org/10.1002/med.2610070103

Lv Z, Zhang L, Tang K (2017) New insights into artemisinin regulation. Plant Signal Behav 12:e1366398. https://doi.org/10.1080/ 15592324.2017 .1366398

Lv Z, Guo Z, Zhang L, Zhang F, Jiang W, Shen Q, Ma Y (2019) Interaction of bZIP transcription factor TGA6 with salicylic acid signaling modulates artemisinin biosynthesis in Artemisia аппиа. J Exp Bot 70:3969-3979. https://doi.org/10.1093/jxb/ erz166

Ma C, Wang H, Lu X, Wang H, Xu G, Liu B (2009a) Terpenoid metabolic profiling analysis of transgenic Artemisia апnиa L. by comprehensive two-dimensional gas chromatography time-of-flight mass spectrometry. Metabolomics 5:497-506. https://doi.org/10. 1007/s11306-009-0170-6

Ma D, Pu G, Lei C, Ma L, Wang H, Guo Y, Ye H (2009b) Isolation and characterization of AaWRKY1, an Artemisia annua transcription factor that regulates the amorpha-4, 11-diene synthase gene, a key gene of artemisinin biosynthesis. Plant Cell Physiol 50:2146-2161. https://doi.org/10.1093/pcp/pcp149

Ma DM, Wang Z, Wang L, Alejos-Gonzales F, Sun MA, Xie DY (2015) A genome-wide scenario of terpene pathways in selfpollinated Artemisia annua. Mol Plant 8:1580-1598. https://doi. org/10.1016/j.molp.2015.07.004

Ma YN, Xu DB, Li L, Zhang F, Fu XQ, Shen Q, Hao XL (2018) Jasmonate promotes artemisinin biosynthesis by activating the TCP14-ORA complex in Artemisia annua. Sci Adv 4:9357. https://doi.org/10.1126/sciadv.aas9357

Ma T, Gao H, Zhang D, Shi Y, Zhang T, Shen X, Chen S (2020) Transcriptome analyses revealed the ultraviolet $\mathrm{B}$ irradiation and phytohormone gibberellins coordinately promoted the accumulation of artemisinin in Artemisia Annua L. Chinese Med. https:// doi.org/10.1186/s13020-020-00344-8

Maes L, Van Nieuwerburgh FC, Zhang Y, Reed DW, Pollier J, Vande Casteele SR, Inzé D, Covello PS, Deforce DL, Goossens A (2011) Dissection of the phytohormonal regulation of trichome formation and biosynthesis of the antimalarial compound artemisinin in Artemisia annua plants. New Phytol 189:176-189. https://doi.org/10.1111/j.1469-8137.2010.03466.x

Mandal S, Upadhyay S, Wajid S, Ram M, Jain DC, Singh VP, Kapoor R (2015) Arbuscular mycorrhiza increase artemisinin accumulation in Artemisia annua by higher expression of key biosynthesis genes via enhanced jasmonic acid levels. Mycorrhiza 25:345357. https://doi.org/10.1007/s00572-014-0614-3

Mannan A, Liu C, Arsenault PR, Towler MJ, Vail DR, Lorence A, Weathers PJ (2010) DMSO triggers the generation of ROS leading to an increase in artemisinin and dihydroartemisinic acid in Artemisia annua shoot cultures. Plant Cell Rep 29:143-152. https://doi.org/10.1007/s00299-009-0807-y

Martini MC, Zhang T, Williams JT, Abramovitch R, Weathers PJ, Shell S (2020) Artemisia annua and Artemisia afra extracts exhibit strong bactericidal activity against Mycobacterium tuberculosis. J Ethnopharmacol 262:113191

Matsushita Y, Kang W, Charlwood BV (1996) Cloning and analysis of a cDNA encoding farnesyl diphosphate synthase from Artemisia апnиa. Gene 172:207-209. https://doi.org/10.1016/03781119(96)00054-6

Mercke P, Bengtsson M, Bouwmeester HJ, Posthumus MA, Brodelius PE (2000) Molecular cloning, expression, and characterization of amorpha-4, 11-diene synthase, a key enzyme of artemisinin biosynthesis in Artemisia annua L. Arch Biochem Biophys 381:173-180. https://doi.org/10.1006/abbi.2000.1962

Mesa LE, Vasquez D, Lutgen P, Restrepo AM, Ortiz I, Robledo SM (2017) In vitro and in vivo antileishmanial activity of Artemisia аппиа L. leaves powder and its potential usefulness in the treatment of uncomplicated cutaneous leishmaniasis in humans. Rev Soc Bras Med Trop 50:52-60. https://doi.org/10.1590/ 0037-8682-0457-2016

Miller LH, Su X (2011) Artemisinin: discovery from the Chinese herbal garden. Cell 146:855-858. https://doi.org/10.1016/j.cell. 2011.08.024

Munyangi J, Cornet-Vernet L, Idumbo M, Chen L, Lutgen P, Perronne C, Ngombe N, Bianga J, Mupenda B, Lalukala P, Mergeai G, Mumba D, Towler MJ, Weathers PJ (2018) Effect of Artemisia annua and Artemisia afra tea infusions on schistosomiasis in a large clinical trial. Phytomedicine 51:233-240. https://doi.org/ 10.1016/j.phymed.2018.10.014

Munyangi J, Cornet-Vernet L, Idumbo M, Chen L, Lutgen P, Perronne C, Ngombe N, Bianga J, Mupenda B, Lalukala P, Mergeai G, Mumba D, Towler MJ, Weathers PJ (2019) Artemisia annua and Artemisia afra tea infusions vs. artesunate-amodiaquine (ASAQ) in treating Plasmodium falciparum malaria in a large scale, double blind, randomized clinical trial. Phytomedicine 57:49-56. https://doi.org/10.1016/j.phymed.2018.12.002

Naeem M, Aftab T, Ansari AA, Shabbir A, Khan MMA, Uddin M (2019) Arsenic exposure modulates physiological attributes and artemisinin biosynthesis in Artemisia аппиа L. Int J Herb Med 7:19-26

Nafis T, Akmal M, Ram M, Alam P, Ahlawat S, Mohd A, Abdin MZ (2011) Enhancement of artemisinin content by constitutive expression of the HMG-CoA reductase gene in high-yielding strain of Artemisia annua L. Plant Biotechnol Rep 5:53-60. https://doi.org/10.1007/s11816-010-0156-x

Nair MS, Huang Y, Fidock DA, Polyak SJ, Wagoner J, Towler MJ, Weathers PJ (2021) Artemisia annua L. extracts prevent in vitro replication of SARS-CoV-2 and two of its variants. J Ethnopharmacol 274:114016. https://doi.org/10.1016/j.jep.2021.114016

$\mathrm{Naß}$ J, Efferth T (2018) The activity of Artemisia spp and their constituents against trypanosomiasis. Phytomedicine 47:184-191. https://doi.org/10.1016/j.phymed.2018.06.002

Nguyen KT, Towler MJ, Weathers PJ (2013) The effect of roots and media constituents on trichomes and artemisinin production in Artemisia annua L. Plant Cell Rep 32:207-218. https://doi.org/ 10.1007/s00299-012-1355-4

Olsson ME, Olofsson LM, Lindahl AL, Lundgren A, Brodelius M, Brodelius PE (2009) Localization of enzymes of artemisinin biosynthesis to the apical cells of glandular secretory trichomes of Artemisia апnиa L. Phytochemistry 70:1123-1128. https://doi. org/10.1016/j.phytochem.2009.07.009

Onimus M, Carteron S, Lutgen P (2013) The surprising efficiency of Artemisia annua powder capsules. Med Aromat Plants 2:21672412. https://doi.org/10.4172/2167-0412.1000125

Paddon CJ, Keasling JD (2014) Semi-synthetic artemisinin: a model for the use of synthetic biology in pharmaceutical development. Nat Rev Microbiol 12:355-367. https://doi.org/10.1038/nrmicro3240

Paddon CJ, Westfall PJ, Pitera DJ, Benjamin K, Fisher K, McPhee D, Leavell MD, Tai A, Main A, Eng D, Polichuk DR (2013) 
High-level semi-synthetic production of the potent antimalarial artemisinin. Nature 496:528-532. https://doi.org/10.1038/natur e12051

Pu GB, Ma DM, Chen JL, Ma LQ, Wang H, Li GF, Liu BY (2009) Salicylic acid activates artemisinin biosynthesis in Artemisia аппиа L. Plant Cell Rep 28:1127-1135. https://doi.org/10.1007/ s00299-009-0713-3

Pulice G, Pelaz S, Matías-Hernández L (2016) Molecular farming in Artemisia апnиа, a promising approach to improve anti-malarial drug production. Front Plant Sci 7:329. https://doi.org/10.3389/ fpls.2016.00329

Qian Z, Gong K, Zhang L, Lv J, Jing F, Wang Y, Tang K (2007) A simple and efficient procedure to enhance artemisinin content in Artemisia апnиa L. by seeding to salinity stress. Afr J Biotechnol 6.

Qin W, Xie L, Li Y, Liu H, Fu X, Chen T, Tang K (2021) An R2R3MYB transcription factor positively regulates the glandular secretory trichome initiation in Artemisia аппиа L. Front Plant Sci 12:560. https://doi.org/10.3389/fpls.2021.657156

Qureshi MI, Israr M, Abdin MZ, Iqbal M (2005) Responses of Artemisia аппиа L. to lead and salt-induced oxidative stress. Environ Exp Bot 53:185-193. https://doi.org/10.1016/j.envexpbot.2004. 03.014

Ram M, Khan MA, Jha P, Khan S, Kiran U, Ahmad MM, Abdin MZ (2010) HMG-CoA reductase limits artemisinin biosynthesis and accumulation in Artemisia annua L. plants. Acta Physiol Plant 32:859-866. https://doi.org/10.1007/s11738-010-0470-5

Ro DK, Paradise EM, Ouellet M, Fisher KJ, Newman KL, Ndungu JM, Chang MC (2006) Production of the antimalarial drug precursor artemisinic acid in engineered yeast. Nature 440:940-943. https://doi.org/10.1038/nature04640

Salehi M, Karimzadeh G, Naghavi MR, Badi HN, Monfared SR (2018) Expression of key genes affecting artemisinin content in five Artemisia species. Sci Rep 8:12659. https://doi.org/10.1038/ s41598-018-31079-0

Sangwan NS, Kumar R, Srivastava S, Kumar A, Gupta A, Sangwan RS (2010) Recent developments on secondary metabolite biosynthesis in Artemisia annua L. J Plant Biol 37:1-24

Schramek N, Wang H, Römisch-Margl W, Keil B, Radykewicz T, Winzenhörlein B, Liu B (2010) Artemisinin biosynthesis in growing plants of Artemisia annua. A 13CO2 study. Phytochemistry 71:179-187. https://doi.org/10.1016/j.phytochem.2009.10. 015

Shen Q, Lu X, Yan T, Fu X, Lv Z, Zhang F, Tang K (2016) The jasmonate-responsive Aa MYC 2 transcription factor positively regulates artemisinin biosynthesis in Artemisia аппиа. New Phytol 210:1269-1281. https://doi.org/10.1111/nph.13874

Shi C, Li H, Yang Y, Hou L (2015) Anti-inflammatory and immunoregulatory functions of artemisinin and its derivatives. Med Inflamm. https://doi.org/10.1155/2015/435713

Shukla A, Farooqi AA, Shukla YN, Sharma S (1992) Effect of triacontanol and chlormequat on growth, plant hormones and artemisinin yield in Artemisia annua L. Plant Growth Regul 11:165-171. https://doi.org/10.1007/BF00024071

Singh ND, Kumar S, Daniell H (2016) Expression of $\beta$-glucosidase increases trichome density and artemisinin content in transgenic Artemisia annua plants. Plant Biotechnol J 14:1034-1045. https://doi.org/10.1111/pbi.12476

Sixt M, Schmidt A, Mestmäcker F, Huter MJ, Uhlenbrock L, Strube J (2018) Systematic and model-assisted process design for the extraction and purification of Artemisinin from Artemisia annиa L.-Part I: conceptual process design and cost estimation. Processes 6:161. https://doi.org/10.3390/pr6090161

Smith LMJ, Bentley S, Jones H, Burns C, Aroo RRJ, Woolley JG (2010) Developing an alternative UK industrial crop Artemisia аппиа, for the extraction of artemisinin to treat multi-drug resistant malaria. Asp Appl Biol 101:99-106

Snider D, Weathers PJ (2021) In vitro reduction of Plasmodium falciparum gametocytes: Artemisia spp tea infusions vs artemisinin. J Ethnopharmacol 268:113638. https://doi.org/10.1016/j.jep. 2020.113638

Soni P, Abdin MZ (2017) Water deficit-induced oxidative stress affects artemisinin content and expression of proline metabolic genes in Artemisia anпua L. FEBS Open Bio 7:367-381. https://doi.org/ 10.1002/2211-5463.12184

Suberu J, Gromski PS, Nordon A, Lapkin A (2016) Multivariate data analysis and metabolic profiling of artemisinin and related compounds in high yielding varieties of Artemisia annua field-grown in Madagascar. J Pharm Biomed Anal 117:522-531. https://doi. org/10.1016/j.jpba.2015.10.003

Sun W, Han X, Wu S, Wu J, Yang C, Li X (2019) Unexpected mechanism of colitis amelioration by artesunate, a natural product from Artemisia аппиа L. Inflammopharmacology. https://doi.org/10. 1007/s10787-019-00678-2

Tang K, Shen Q, Yan T, Fu X (2014) Transgenic approach to increase artemisinin content in Artemisia annua L. Plant Cell Rep 33:605-615. https://doi.org/10.1007/s00299-014-1566-y

Torelli A, Trotta A, Acerbi I, Arcidiacono G, Berta G, Branca C (2000) IAA and ZR content in leek (Allium porrum L.) as influenced by P-nutrition and arbuscular mycorrhizae, in relation to plant development. Plant Soil 226:29-35. https://doi.org/10.1023/A: 1026430019738

Towler MJ, Weathers PJ (2007) Evidence of artemisinin production from IPP stemming from both the mevalonate and the nonmevalonate pathways. Plant Cell Rep 26:2129-2136. https://doi.org/ 10.1007/s00299-007-0420-x

Towler MJ, Weathers PJ (2015) Variations in key artemisinic and other metabolites throughout plant development in a clonal cultivar of Artemisia annua for possible therapeutic use. Ind Crops Prod 67:185-191. https://doi.org/10.1016/j.indcrop.2015.01.007

Townsend T, Segura V, Chigeza G, Penfield T, Rae A, Harvey D et al (2013) The use of combining ability analysis to identify elite parents for Artemisia annua $\mathrm{F} 1$ hybrid production. PLoS ONE 8:e61989. https://doi.org/10.1371/journal.pone.0061989

Vashisth D, Kumar R, Rastogi S, Patel VK, Kalra A, Gupta MM, Shasany AK (2018) Transcriptome changes induced by abiotic stresses in Artemisia annua. Sci Rep 8:1-14. https://doi.org/10. 1038/s41598-018-21598-1

Wang Y, Zhang H, Zhao B, Yuan X (2001) Improved growth of Artemisia annиa $\mathrm{L}$. hairy roots and artemisinin production under red light conditions. Biotechnol Lett 23:1971-1973. https://doi.org/ 10.1023/A:1013786332363

Wang Y, Jing F, Yu S et al (2011) Co-overexpression of the HMGR and FPS genes enhances artemisinin content in Artemisia annua $\mathrm{L}$. J Med Plants Res 5:3396-3403. https://doi.org/10.5897/JMPR. 9000369

Wang Z, Yang L, Yang X, Zhang X (2014) Advances in the chemical synthesis of artemisinin. Synth Commun 44:1987-2003. https:// doi.org/10.1080/00397911.2014.884225

Wang S, Towler MJ, Weathers PJ (2016) Root regulation of artemisinin production in Artemisia annua: trichome and metabolite evidence. Planta 244:999-1010. https://doi.org/10.1007/ s00425-016-2560-0

Wetzstein HY, Porter JA, Janick J, Ferreira JF, Mutui TM (2018) Selection and clonal propagation of high artemisinin genotypes of Artemisia annua. Front Plant Sci 9:358. https://doi.org/10.3389/ fpls.2018.00358

White NJ (2008) Qinghaosu (Artemisinin) the price of success. Science 320:331-334. https://doi.org/10.1126/science.1155165 
WHO (2006) WHO monograph on good agricultural and collection practices (GACP) for Artemisia аппиа L. World Health Organization.

Widmer V, Handloser D, Reich E (2007) Quantitative HPTLC analysis of artemisinin in dried Artemisia апnиа L.: a practical approach. J Liq Chromatogr Relat Technol 30:2209-2219. https://doi.org/ 10.1080/10826070701451555

Wu Z, Li L, Liu H, Yan X, Ma Y, Li Y, Tang K (2021) AaMYB15, an R2R3-MYB TF in Artemisia anпиa, acts as a negative regulator of artemisinin biosynthesis. Plant Sci. https://doi.org/10.1016/j. plantsci.2021.110920

Xiang L, Zeng L, Yuan Y, Chen M, Wang F, Liu X, Liao Z (2012) Enhancement of artemisinisn biosynthesis by overexpressing $d x r$, cyp7lav1 and cpr in the plants of Artemisia annua L. Plant Omics 5:503

Xiang L, Zhu S, Zhao T, Zhang M, Liu W, Chen M, Liao Z (2015) Enhancement of artemisinin content and relative expression of genes of artemisinin biosynthesis in Artemisia аппиа by exogenous MeJA treatment. Plant Growth Regul 75:435-441. https:// doi.org/10.1007/s10725-014-0004-Z

Xiang L, Jian D, Zhang F, Yang C, Bai G, Lan X, Liao Z (2019) The cold-induced transcription factor bHLH112 promotes artemisinin biosynthesis indirectly via ERF1 in Artemisia annua. J Exp Bot 70:4835-4848. https://doi.org/10.1093/jxb/erz220

Xie DY, Ma DM, Judd R, Jones AL (2016) Artemisinin biosynthesis in Artemisia апnиa and metabolic engineering: questions, challenges, and perspectives. Phytochem Rev 15:1093-1114. https:// doi.org/10.1007/s11101-016-9480-2

Yadav RK, Sangwan RS, Sabir F, Srivastava AK, Sangwan NS (2014) Effect of prolonged water stress on specialized secondary metabolites, peltate glandular trichomes, and pathway gene expression in Artemisia annua L. Plant Physiol Biochem 74:70-83. https:// doi.org/10.1016/j.plaphy.2013.10.023

Yan L, He-Chun Y, Hong W et al (2003) Molecular cloning, Escherichia coli expression and genomic organization of squalene synthase gene from Artemisia annua. Acta Bot Sin 45:608-613

Yang RY, Zeng XM, Lu YY, Lu WJ, Feng LL, Yang XQ, Zeng QP (2010) Senescent leaves of Artemisia annua are one of the most active organs for overexpression of artemisinin biosynthesis responsible genes upon burst of singlet oxygen. Planta Med 76:734-742. https://doi.org/10.1055/s-0029-1240620

Yang H, Wu J, Tang T, Liu K, Dai C (2017) CRISPR/Cas9-mediated genome editing efficiently creates specific mutations at multiple loci using one sgRNA in Brassica napus. Sci Rep 7:7489

Yin LL, Zhao C, Huang Y, Yang RY, Zeng QP (2008) Abiotic stressinduced expression of artemisinin biosynthesis genes in Artemisia annua L. ·用與環境生物學報 14:1-5.

Yu ZX, Li JX, Yang CQ, Hu WL, Wang LJ, Chen XY (2012) The jasmonate-responsive AP2/ERF transcription factors AaERF1 and AaERF2 positively regulate artemisinin biosynthesis in Artemisia аппиа L. Mol Plant 5:353-365. https://doi.org/10.1093/ $\mathrm{mp} / \mathrm{ssr} 087$
Zebarjadi A, Dianatkhah S, Mohammadi PP, Qaderi A (2018) Influence of abiotic elicitors on improvement production of artemisinin in cell culture of Artemisia annua L. Cell Mol Biol 64:1-5

Zehra A, Choudhary S, Wani KI, Naeem M, Khan MMA, Aftab T (2020) Exogenous abscisic acid mediates ROS homeostasis and maintains glandular trichome to enhance artemisinin biosynthesis in Artemisia annua under copper toxicity. Plant Physiol Biochem. https://doi.org/10.1016/j.plaphy.2020.08.048

Zeng AH, Ou YY, Guo MM, Dai X, Zhou DZ, Chen R (2015) Human embryonic lung fibroblasts treated with artesunate exhibit reduced rates of proliferation and human cytomegalovirus infection in vitro. J Thorac Dis 7:1151-1157. https://doi.org/10. 3978/j.issn.2072-1439.2015.07.05

Zhang L, Jing F, Li F, Li M, Wang Y, Wang G, Tang K (2009) Development of transgenic Artemisia annиa (Chinese wormwood) plants with an enhanced content of artemisinin, an effective anti-malarial drug, by hairpin-RNA-mediated gene silencing. Biotechnol Appl Biochem 52:199-207. https://doi.org/10.1042/BA20080068

Zhang F, Lu X, Lv Z, Zhang L, Zhu M, Jiang W, Tang K (2013) Overexpression of the Artemisia orthologue of ABA receptor, AaPYL9, enhances ABA sensitivity and improves artemisinin content in Artemisia annua L. PLoS ONE 8:e56697. https://doi. org/10.1371/journal.pone.0056697

Zhang F, Fu X, Lv Z, Lu X, Shen Q, Zhang L, Tang K (2015) A basic leucine zipper transcription factor, AabZIP1, connects abscisic acid signaling with artemisinin biosynthesis in Artemisia annиа. Mol Plant 8:163-175. https://doi.org/10.1016/j.molp.2014.12. 004

Zheng H, Colvin CJ, Johnson BK, Kirchhoff PD, Wilson M, JorgensenMuga K, Larsen SD, Abramovitch RB (2017) Inhibitors of Mycobacterium tuberculosis DosRST signaling and persistence. Nat Chem Biol 13:218. https://doi.org/10.1038/nchembio.2259

Zhong Y, Li L, Hao X, Fu X, Ma Y, Xie L, Tang K (2018) AaABF3, an abscisic acid-responsive transcription factor, positively regulates artemisinin biosynthesis in Artemisia aпnиa. Front Plant Sci 9:1777. https://doi.org/10.3389/fpls.2018.01777

Zhou M, Memelink J (2016) Jasmonate-responsive transcription factors regulating plant secondary metabolism. Biotechnol Adv 34:441-449. https://doi.org/10.1016/j.biotechadv.2016.02.004

Zhou L, Yang G, Sun H, Tang J, Yang J, Wang Y, Guo L (2017) Effects of different doses of cadmium on secondary metabolites and gene expression in Artemisia annua L. Front Med 11:137-146. https:// doi.org/10.1007/s11684-016-0486-3

Zhou Z, Tan H, Li Q, Li Q, Wang Y, Bu Q, Zhang L (2020) Trichome and artemisinin regulator 2 positively regulates trichome development and artemisinin biosynthesis in Artemisia annиa. New Phytol 228:932-945. https://doi.org/10.1111/nph.16777

Publisher's Note Springer Nature remains neutral with regard to jurisdictional claims in published maps and institutional affiliations. 